\title{
Cristão secularizado: contribuições de Hans Küng para a vivência da fé cristã no mundo de secularização
}

\author{
Orientador: Joel Portella Amado \\ Mestrando: Ismael Souza \\ Área de Concentração: Teologia Sistemático-Pastoral \\ Linha de Pesquisa: Fé e Cultura
}

O processo de secularização do mundo ocidental trouxe, em sua esteira, diversas implicações teológico-pastorais para o cristianismo. Diante desta realidade, as Igrejas cristãs e cristãos necessitam de articulação para apresentar à seus contemporâneos a mensagem de Jesus de Nazaré de forma contextualizada. Com o objetivo de encontrar um caminho lúcido para responder às interpelações da sociedade secularizada, esta pesquisa recorreu às reflexões do teólogo Hans Küng, que permitiu responder as implicações e firmar a convicção à fé cristã e, sua relevância na atualidade e futuro. Após reconhecer o ambiente urbano, onde normalmente se desenvolvem as ações pastorais, percebe-se que, a Igreja Católica e as Igrejas da senda protestante, necessitam contextualizar e reformular a própria teologia e práxis, em seus níveis institucional, social e individual, sendo apresentadas propostas pastorais com este propósito. Concernente ao futuro, mesmo não sendo possível total previsibilidade, o cristianismo, na Europa, se encontra numa situação mais delicada do que na América do Norte e, principalmente, se comparado à América Latina, onde parece promissor. Observando o itinerário desta pesquisa, pode-se concluir que, ser Igreja e cristão secularizado, significa viver como Jesus viveu. Jesus de Nazaré pode ser apresentado, para crentes e não-crente, como expressão máxima de humanidade para todos os séculos, por ter vivido radicalmente a existência humana, constituindo-se como paradigma. Jesus foi radicalmente secular porque radicalmente se fez humano, mesmo sendo o "Filho de Deus".

Palavras-chave: Ateísmo; Cristianismo; Efervescência Religiosa; Fé; Hans Küng. 